Click www.researchjournal.co.in/online/subdetail.html to purchase.

INTERNATIONAL JOURNAL OF PLANT PROTECTION

- ISSN-0974-2670 | Visit us : www.researchjournal.co.in

DOI : 10.15740/HAS/IJPP/13.2/205-206

\title{
Stem borer incidence in maize
}

M. Anuradha* and Lavkumar Reddy

Maize Research Cenntre, Rajendranagar, Hyderabad (Telangana) India

ARITCLE INFO

Received : 29.07 .2020

Revised : 12.09 .2020

Accepted : 25.09 .2020

\section{KEY WORDS :}

Date of sowing, Deadhearts, Maize, Stemborer

*Corresponding author:

Email : kasuanu@yahoo.co.in

\begin{abstract}
Field experiment was conducted at Maize Research Centre, Rajendranagar by undertaking sowings at monthly intervals from January to December during two years 2013 and 2014. Observations on stemborer incidence was recorded at 45 DAG and subjected to analysis after angular transformation. June sown crop had lowest infestation of 2.83 per cent followed by December (3.35\%) and May (3.69\%) sown crops and all were significantly on par. Dead hearts were low in April, May and December sown crops i.e., 0.11 per cent, 0.15 per cent and 0.55 per cent, respectively and all were on par with each other. Highest per cent dead hearts were in Sep. sown crop (7.67\%).
\end{abstract}

How to view point the article : Anuradha, M. and Reddy, Lavkumar (2020). Stem borer incidence in maize. Internat. J. Plant Protec., 13(2) : 205-206, DOI : 10.15740/HAS/IJPP/13.2/ 205-206,Copyright@2020: Hind Agri-Horticultural Society. 